\title{
ANALISIS KUALITAS SELADA (Lactuca sativa L.) YANG DITANAM PADA DUA MEDIA SELAMA PENYIMPANAN DINGIN
}

\author{
Analysis of Lettuce (Lactuca sativa L.) Quality Planted on Two Media during Cold \\ Storage
}
Livia E. Rantung ${ }^{1 *}$, Lady C. Ch. E. Lengkey ${ }^{2)}$, Frans Wenur ${ }^{2)}$
${ }^{1)}$ Mahasiswa Program Studi Teknik Pertanian
${ }^{2)}$ Dosen Program Studi Teknik Pertanian
Jurusan Teknologi PertanianFakultas Pertanian, Universitas Sam Ratulangi Manado

*e-mail: liviaeugeniarantung@gmail.com

\begin{abstract}
The objective of this study was to investigate the quality (weight, color, stem firmness and total dissolved solids) of hydroponic and soil culture lettuce (Lactuca sativa L.). This study used a non factorial completely randomized design with two treatments (type of planting media) as follows hydroponic lettuce and soil culture lettuce. This research conducted 9 replications. Data were analyze with ANOVA to determine whether there is a difference in the quality of lettuce after storage at cold temperatures. Lettuce is packed and placed at cold storage of $5^{0} \mathrm{C}$. The change in weight, color, stem firmness and total dissolved solids were observed every 3 days during storage period. The result of this study show that hydroponic lettuce and soil lettuce gave different responses during cold storage. After 15 days of storage, soil culture lettuce has better quality than hydroponic lettuce in terms of maintaning the weight and total dissolved solids. While, in maintaning the color and firmness of the stem, hydroponic lettuce has better quality.
\end{abstract}

Keywords: Lettuce, planting media, cold storage

\section{PENDAHULUAN}

Selada (Lactuca sativa L.) merupakan salah satu komoditi hortikultura yang memiliki prospek dan nilai komersial yang cukup baik. Ditinjau dari aspek klimatologis, aspek teknis, ekonomis dan bisnis, selada layak diusahakan untuk memenuhi permintaan konsumen yang cukup tinggi dan peluang pasar internasional yang cukup besar (Haryanto et al, 2003). Menurut Harris
(1989), sayuran dan buah sangat bergantung pada fotosintesis dan penyerapan air maupun mineral. Proses fotosintesis dan penyerapan air maupun mineral tanaman juga bergantung pada aspek ekologi, termasuk di dalamnya media tanam. Selada (Lactuca sativa L.) adalah tanaman yang bisa dibudidayakan pada berbagai macam media tanam, termasuk di tanah dan hidroponik. Pada saat pembudidayaan, pemberian nutrisi, perawatan dan pemanenan yang dilakukan 
pada setiap media tanam adalah berbeda tergantung pada jenis media tanamnya sehingga bisa saja kualitas yang dihasilkan oleh selada yang ditanam pada setiap media tanam berbeda. Untuk itu, perlu dilakukan analisis kualitas selada yang ditanam dengan pada kedua media tersebut dalam hal kualitas pascapanennya setelah diberikan penanganan.

Salah satu penanganan pascapanen yang dapat dilakukan adalah penyimpanan suhu rendah atau penyimpanan dingin. Penyimpanan dingin dilakukan agar umur simpan dan kesegaran dapat dipertahankan, dimana penggunaan suhu rendah dapat menekan aktivitas metabolisme pada selada.

Penelitian ini bertujuan untuk menganalisis perbedaan kualitas pascapanen (susut bobot, warna, kekerasan batang, dan total padatan terlarut) selada (Lactuca sativa L.) yang ditanam dengan media berbeda selama penyimpanan dingin. Diduga terdapat perbedaan kualitas pascapanen (Susut bobot, warna, tekstur dan total padatan terlarut) selada (Lactuca sativa L.) yang ditanam dengan media berbeda selama penyimpanan dingin.

\section{METODE PENELITIAN}

\section{Bahan dan Alat}

Bahan yang digunakan dalam penelitian ini adalah selada (Lactuca sativa L.) keriting hijau (green lollo) yang dipanen di Kota Tomohon. Selada yang ditanam di tanah diambil dari petani selada di Kelurahan Kakaskasen Dua sedangkan selada hidoponik diambil dari PT. Kawanua Agri Maya. Umur panen selada tanah adalah 38 HST sedangkan selada hidroponik adalah 33 HST. Selada yang dipanen segera dibawa ke Laboratorium Pascapanen Teknik Pertanian UNSRAT untuk disimpan. Bahan lain yang digunakan adalah disinfektan untuk mereduksi mikroba saat perlakuan pra pendinginan, air dan hancuran es untuk memindahkan panas saat melakukan pra pendinginan.

Alat yang digunakan pada penelitian ini adalah rermometer alkohol, termometer bahan, termohigrometer, penetrometer, aplikasi Color Grab pada ponsel Oppo A3s, refraktometer digital, timbangan digital, lemari pendingin, lampu meja LED, alat tulis menulis, plastik, dan box styrofoam.

\section{Rancangan Penelitian}

Penelitian ini menggunakan metode RAL (Rancangan Acak Lengkap) dengan 2 perlakuan (jenis media tanam) yaitu selada hidroponik dan selada yang ditanam di tanah. Setiap perlakuan diulang sebanyak 9 kali. Data dianalisis dengan analysis of variance (ANOVA) untuk mengetahui apakah ada terdapat perbedaan kualitas kedua selada setelah disimpan pada suhu dingin.

\section{Prosedur Penelitian}

Persiapan meliputi penanaman, panen, sortasi, dan pencucian. Setelah dipanen, selada yang ditanam ditanah dicuci dengan air untuk dibersihkan dari kotoran yang menempel. Setelah itu, selada disortasi untuk memilih sayur yang sehat dan seragam. Penelitian menggunakan perlakuan penanganan pascapanen selada dengan penyimpanan dingin. Sebelum masuk pada penyimpanan dingin, diawali terlebih dahulu dengan pra-pendinginan. Prapendinginan awalnya dilakukan dengan metode contact ice selama transportasi dari lokasi pemanenan ke Laboratorium. Selanjutnya, pra-pendinginan dilakukan dengan metode hydrocooling dengan penambahan klorin sebesar $5 \mathrm{ppm}$. Penanganan hydrocooling menurut Dewi (2008) yaitu merendam sampel selada pada air es dengan suhu $3-5^{0} \mathrm{C}$ selama 5 menit kemudian dikeringkan dengan kain tisu dan dikemas dengan plastik. Menurut Sagas et al (2015), secara teoritis, 
penentuan jumlah es yang dibutuhkan untuk menurunkan temperatur menggunakan persamaan berikut:

dimana:

$$
m_{1} C \Delta T=m_{2} L_{f}
$$

$\mathrm{m}_{1}=$ Massa air $(\mathrm{kg})$;

$\mathrm{C}=$ Panas jenis air $(4,180 \mathrm{KJ} / \mathrm{kg})$

$\Delta \mathrm{T}=$ Perbedaan temperatur air awal dan temperatur air akhir $\left({ }^{0} \mathrm{C}\right)$

$\mathrm{m}_{2}=$ Massa es $(\mathrm{kg})$

$\mathrm{L}_{\mathrm{f}}=$ Panas laten peleburan es $(333 \mathrm{KJ} / \mathrm{kg})$.

Selada yang ditanam di tanah dan

selada hidroponik kemudian dikemas dalam plastik. Masing-masing plastik terdiri dari 1 selada dalam tiap kemasan. Selada kemudian disimpan di lemari pendingin pada suhu $5^{0} \mathrm{C}$.

\section{Parameter Penelitian}

\section{Susut Bobot}

Untuk mengukur susut bobot digunakan persamaan sebagai berikut:

$$
\text { Susut Bobot }(\%)=\frac{w-w_{a}}{w} \times 100 \%
$$

dimana:

$\mathrm{w}=$ Bobot awal penyimpanan $(\mathrm{g})$

$\mathrm{w}_{\mathrm{a}}=$ Bobot akhir penyimpanan $(\mathrm{g})$

Warna

Pengukuran warna dilakukan dengan menggunakan aplikasi Color Grab pada telepon genggam android Oppo A3s. Sistem notasi warna yang digunakan adalah sistem CIE L a b, dimana L adalah untuk terang gelap (kecerahan), a untuk warna merah dan hijau, dan b untuk warna kuning dan biru.

\section{Kekerasan Batang}

Kekerasan batang diukur dengan menggunakan Penetrometer. Pengukuran kekerasan dilakukan pada batang selada.

\section{Total Padatan Terlarut}

Pengukuran menggunakan refraktometer. Sampel diambil dengan cara menghancurkan sampel dan diteteskan pada prisma refraktometer.
Hasil akan tertera pada layar dengan satuan ${ }^{0}$ brix.

\section{HASIL DAN PEMBAHASAN}

\section{Susut Bobot}

Data penyusutan bobot pada hari ke-15 dianalisis dengan analisis sidik ragam pada selang kepercayaan $95 \%$. Analisis sidik ragam menunjukkan bahwa penyusutan bobot selada hidroponik dan selada tanah berbeda nyata. Artinya, media tanam yang berbeda memicu perbedaan nilai penyusutan bobot selada (Gambar 1).

Menurut Pantastico (1986), meningkatnya susut bobot sebagian besar disebabkan oleh transpirasi yang tinggi. Penyusutan bobot ini disebabkan oleh penguapan air dari jaringan melalui stomata ke lingkungan. Hal lain yang menyebabkan penyusutan bobot adalah respirasi dan aktivitas bakteri. Berdasarkan teori tersebut, dapat dikatakan bahwa selada hidroponik memiliki transpirasi yang lebih besar dibanding selada yang ditanam di tanah sehingga penyusutan bobot selada hidroponik lebih besar daripada selada tanah. Kadar Air dan rasio antara luas permukaan dengan berat yang tinggi dari produk memungkinkan laju penguapan air berlangsung tinggi (Van Den Berg dan Lenz, 1973). Selada hidroponik memiliki rasio antara luas permukaan dengan berat yang tinggi sehingga penguapan air berlangsung tinggi dan lebih mudah mengalami penyusutan. Diduga hal tersebut disebabkan karena intensitas cahaya yang diterima selada dan perbedaan umur panen antara selada hidroponik dan selada tanah, dimana selada hidroponik memiliki umur panen yang lebih muda dibanding selada tanah. 


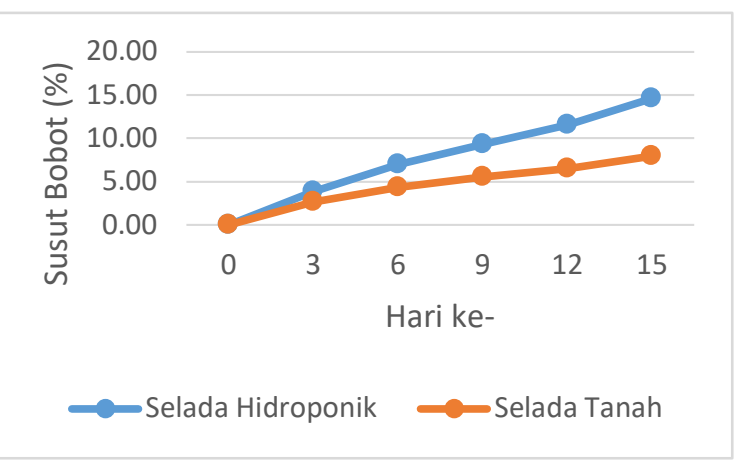

Gambar 1. Penyusutan Bobot Selada

\section{Warna}

Data perubahan warna $\mathrm{L}$, a dan $\mathrm{b}$ pada hari ke-15 dianalisis dengan teknik analisis sidik ragam pada selang kepercayaan 95\%. Berdasarkan hasil analisis sidik ragam 5\% warna $\mathrm{L}$ hari ke15 menunjukkan bahwa warna L kedua perlakuan tidak berbeda nyata. Artinya, kecerahan atau terang gelapnya warna daun selada hidroponik dan selada tanah tidak berbeda nyata. Analisis sidik ragam warna a (warna merah-hijau) menunjukkan kedua perlakuan tidak berbeda nyata. Sedangkan, analisis sidik ragam warna $b$ menunjukkan kedua perlakuan berbeda nyata yaitu adanya perbedaan warna kuning-biru pada daun selada hidroponik dan selada tanah.

Selama penyimpanan tren nilai $\mathrm{L}$, $a$ dan $b$ selada cenderung meningkat (Gambar 2). Artinya, warna selada berubah semakin terang seiring lamanya penyimpanan, kehilangan kehijauanan dan menguning. Menurut Hakiki et al. (2016), hal tersebut diakibatkan karena selada mengalami kehilangan klorofil yang berperan dalam pembentukan warna hijau daun. Klorofil telah terdegradasi secara enzimatik membentuk pigmen warna kuning (karotenoid) dan cokelat (feofitin) (Anonim, t.t.).
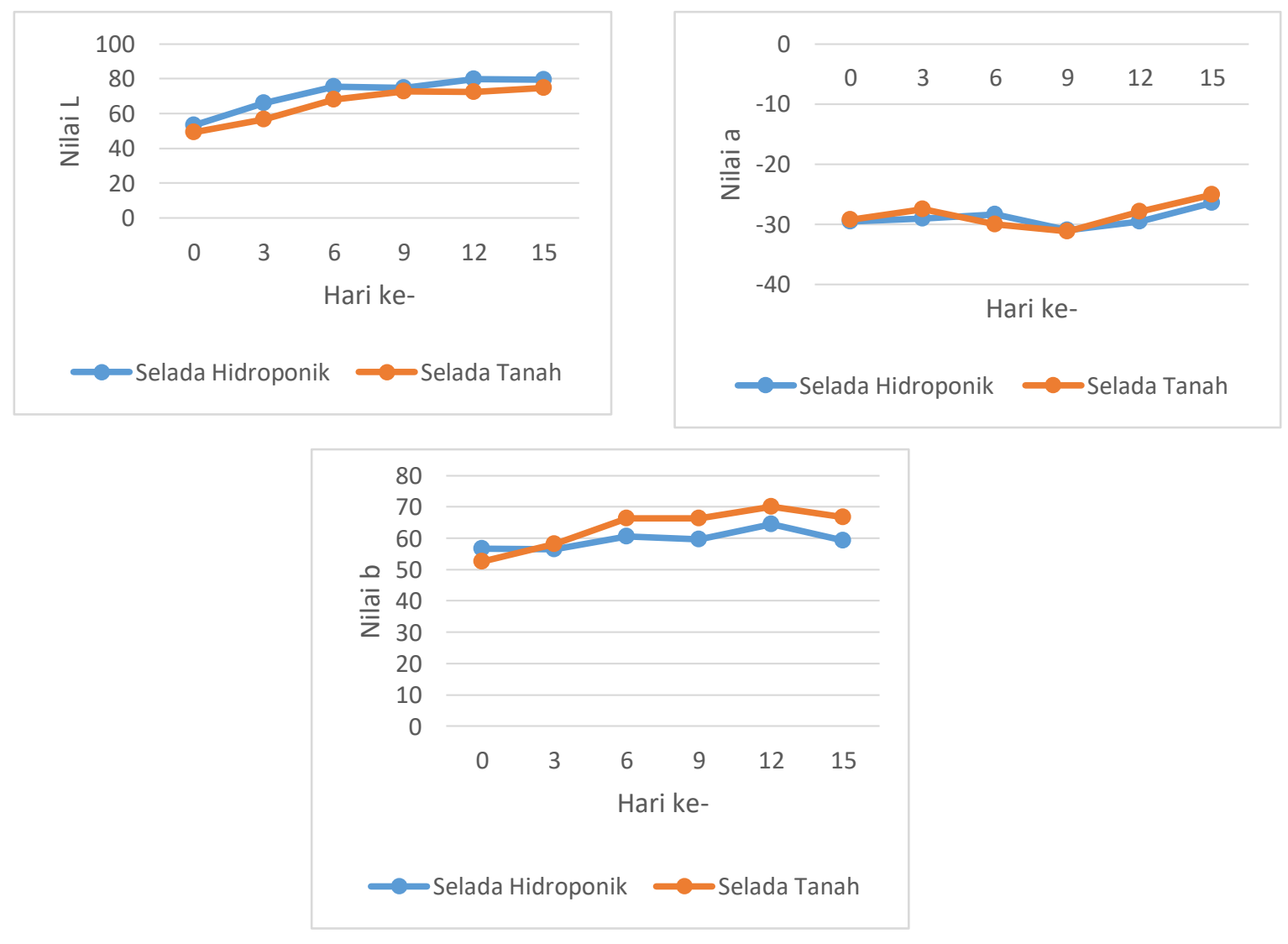

Gambar 2. Grafik warna L, a, dan b selada selama penyimpanan dingin 
Berdasarkan pengamatan, selada tanah lebih rentan mengalami pencokelatan (browning) dibanding dengan selada hidroponik dimana pencokelatan pada selada tanah sudah mulai terlihat pada pengamatan hari ke-6 dan hari ke-9. Aktivitas enzim menjadi penyebab utama reaksi pencokelatan pada selada. Enzim yang terlibat dalam pencokelatan enzimatik dikenal dengan nama polifenoloksidase (PPO). Menurut Mampholo et al (2019), aktivitas PPO pada selada dipengaruhi oleh faktor prapanen yaitu rata-rata aplikasi nitrogen, dimana aktivitas PPO lebih tinggi pada selada dengan aplikasi nitrogen yang rendah. Reaksi pencokelatan ini juga membuat daun selada membusuk dan pembusukan menyebar sampai ke batang sehingga umur simpan selada tanah lebih pendek yaitu kurang dari 15 hari, dibanding umur simpan selada hidroponik yang kurang dari 18 hari. Diduga infeksi laten terjadi pada selada tanah karena selada tanah berhubungan langsung dengan media tanam tanah yang di dalamnya terdapat beragam mikroorganisme. Mikroorganisme tersebut pada saat pertumbuhan dalam keadaan pasif dan baru berkembang setelah selada dipanen.

Sampai akhir penyimpanan, selada yang ditanam di tanah cenderung memiliki nilai $\mathrm{L}$, a dan $\mathrm{b}$ terendah dibanding dengan selada hidroponik. Berdasarkan pengamatan, dapat dijelaskan bahwa selada hidroponik lebih baik mempertahankan warna dibanding selada yang ditanam di tanah, dimana selada hidroponik tidak perubahan warna menjadi kuning dan pencokelatan lebih rentan terjadi .

\section{Kekerasan Batang}

Berdasarkan analisis sidik ragam hari ke-15 menunjukkan bahwa kekerasan selada hidroponik dan selada tanah berbeda nyata. Artinya, jenis media tanam yang berbeda memicu perbedaan nyata terhadap kekerasan batang selada. Pada hari ke-0 menunjukkan bahwa selada hidroponik memiliki nilai kekerasan yang lebih tinggi dibanding selada tanah (Gambar 3). Hal tersebut berhubungan dengan adaptasi selada terhadap media tanam/media tumbuh dan habitat, dimana selada tanah memiliki batang yang lebih keras dibanding selada hidroponik. Lignin berpengaruh terhadap kekerasan batang selada. Aryani (t.t) menyatakan bahwa kandungan lignin paling banyak terdapat pada akar dan batang tua dimana kandungan lignin meningkat seiring dengan meningkatnya umur tanaman sehingga sel-selnya menjadi kuat dan keras.

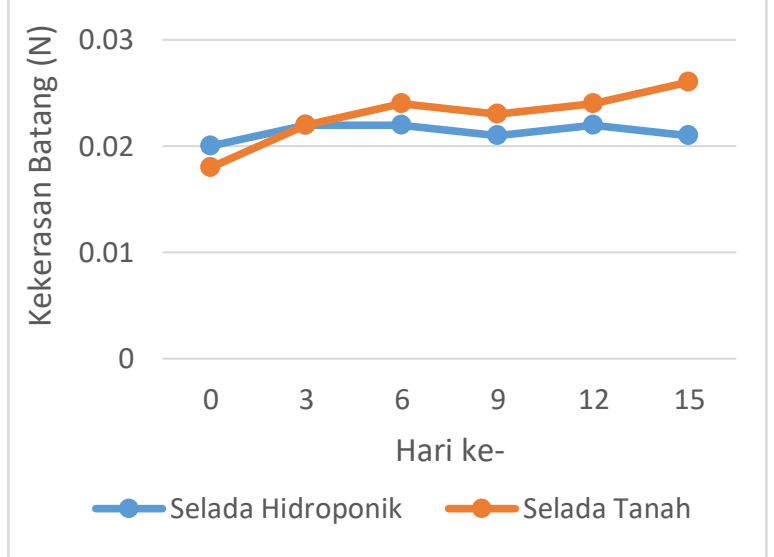

Gambar 3. Rata-Rata Kekerasan Batang Selada

Penurunan kekerasan dipengaruhi oleh kehilangan air dan aktivitas enzim. Menurut Mutia et al (2015), peningkatan nilai kekerasan pada suhu rendah terjadi karena penguapan antar ruang sel yang menyebabkan sel mengerut dan menyatu (zat pektin saling berikatan). Menurut Fitrianti (2006), menurunnya kekerasan terjadi karena degradasi pektin yang dikatalis oleh enzim esterase membentuk asam poligalaktunarat bebas dan metanol serta enzim poligalakturonase. Sementara, penurunan nilai kekerasan dipengaruhi 
oleh pengerasan dinding sel akibat suhu dingin.

Faktor pra panen berpengaruh terhadap kualitas pascapanen yaitu pelunakan. Angeletti, et al. (2010) menyatakan bahwa aplikasi kalsium yang lebih tinggi berguna menunda pelunakan pascapanen. Berdasarkan pengamatan, sampai pada hari ke-15, nilai kekerasan dari selada tanah lebih tinggi dibanding dengan nilai kekerasan selada hidroponik yang artinya batang selada tanah cenderung lebih mudah mengalami pelunakan dan sulit mempertahankankan kekerasannya.

\section{Total Padatan Terlarut}

Analisis sidik ragam hari ke-15 menunjukkan bahwa tidak ada beda nyata total padatan telarut selada hidroponik dengan selada yang ditanam di tanah. Artinya, jenis media tanam yang berbeda tidak memicu perbedaan total padatan terlarut sehingga tidak menunjukkan perbedaan yang nyata pada masingmasing selada. Total padatan terlarut menunjukkan kandungan bahan-bahan terlarut. Total padatan terlarut digunakan untuk menginterpretasikan jumlah gula yang terkandung pada selada.

Total padatan terlarut tertinggi cenderung ditunjukkan oleh selada tanah dengan rata-rata setiap pengamatan 41,71 ${ }^{0}$ Brix sedangkan rata-rata selada hidroponik adalah 41,25 ${ }^{0}$ Brix (Gambar 4).

Pantastico (1986) menyatakan bahwa peningkatan total padatan terlarut disebabkan karena terjadinya pemutusan rantai panjang senyawa-senyawa karbohidrat menjadi senyawa gula yang larut. Penurunan total padatan terlarut menandakan adanya penurunan kadar gula dalam selada. Menurut Fardiaz (1992), nilai total padatan terlarut yang semakin menurun disebabkan oleh adanya proses fermentasi akibat aktivitas bakteri.
Jenis tanah, kompos, mulsa dan pemupukan mempengaruhi komposisi nutrisi setelah panen (Kader, 2002).

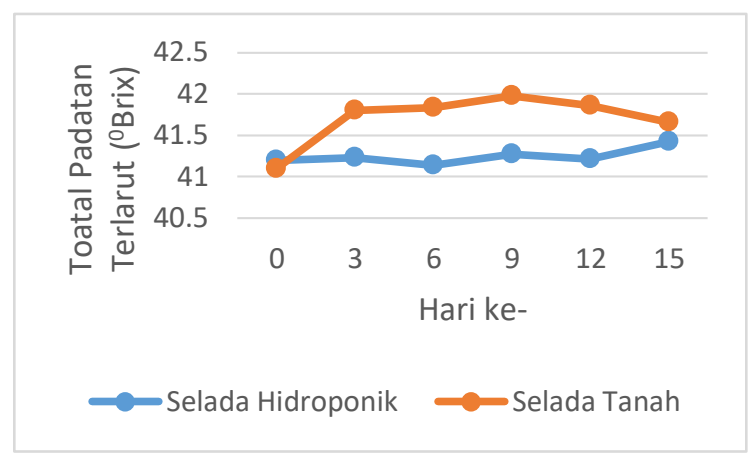

Gambar 4. Rata-Rata Total Padatan Terlarut

Faktor lingkungan seperti cahaya, $\mathrm{CO}_{2}$, kelembaban relatif, suhu, dan kesediaan air berpengaruh terhadap proses fotosintesis (Hewett, 2006). Hal tersebut menjelaskan mengapa terjadi perbedaan nilai kandungan total padatan pada selada tanah dan selada hidroponik, dimana media tanah lebih kaya akan unsur hara dibanding media hidroponik yang hanya mendapat nutrisi dari pemupukan $\mathrm{AB}$ mix. Hasil pengamatan menunjukkan bahwa kandungan total padatan terlarut selada tanah lebih tinggi dibanding selada hidroponik sehingga memiliki kualitas yang lebih baik.

\section{KESIMPULAN}

1. Perbedaan nyata selada tanah dengan selada hidroponik selama penyimpanan terjadi parameter yaitu susut bobot, warna $b$, dan kekerasan batang dan tidak terjadi pada parameter warna L dan warna a, dan total padatan terlarut.

2. Untuk penyimpanan dingin selada tanah dan selada hidroponik, setiap parameter memberikan respon berbeda. Ditinjau dari parameter susut bobot dan total padatan terlarut, selada tanah memiliki kualitas yang lebih baik dibanding selada 
hidroponik. Sementara, ditinjau dari parameter warna dan kekerasan batang selada hidroponik memiliki kualitas yang lebih baik dibanding selada tanah.

\section{DAFTAR PUSTAKA}

Angeletti P., H. Castagnasso, Elisa M., Laura T., Analia C., Alicia C. \& Ariel V. 2010. Effect of Preharves Calcium Applications on Postharvest Quality, Softening and Cell Wal Degradation of Two Blueberry Varieties. Post Harvest Biology and Technology Journal. Argentina. Diakses dari www.elsevier.com pada 20 Juli 2020

Anonim. t.t. Handout Mata Kuliah Terbuka Pengetahuan Bahan Pangan. Universitas Negeri Yogyakarta.

Aryani, A. L., Y. Widodo \& Erwanto. t.t. Analisis Kandungan Serat Kasar pada Tanaman Kiambang (Salvinia molesta) dengan Metode Van Soest di Waduk Batutegi Tanggamus Lampung. Fakultas Pertanian Universitas Lampung. Lampung.

Dewi, A. 2008. Pengaruh Hydrocooling dan Pengemasan terhadap Mutu Pak Choi (Brassica rapa var Chinensis) selama Transportasi Darat. Institut Pertanian Bogor. Bogor

Fitrianti, J. 2006. Kajian Teknik Penyimpanan dan Pengemasan Jambu Biji (Psydium guajava L.) dalam Kemasan Transportasi. IPB (Skripsi)

Hakiki, D.N., E.D., Y. A. Purwanto, U.H \& Yotoma. 2016. Perubahan Kualitas Pascapanen Bayam Organik selama Penyimpanan setelah Perlakuan Heat Shock dan
Hydrocooling. Jurnal Keteknikan Pertanian, Vol. 4 No. 1:56

Harris, R. S. 1989. Evaluasi Gizi pada Pengolahan Bahan Pangan. Institut Teknologi Bandung. Bandung

Haryanto, E. , T. Suhartini \& E. Rahayu. 2003. Sawi dan Selada. Penebar Swadaya. Jakarta

Hewett, E. W. 2006. An Overview of Preharvest Factors Influencing Postharvest Quality of Horticultural Products. International Journal of Postharvest Technology and Innovation.

Kader, A. A. 2002. Pre- and Postharvest Factors Affecting Fresh Produce Quality, Nutritional Values and Implication for Human Health. International Congres Food Production and Quality of Life.

Mampholo B.M., Martin M., Puffy S. dan Dharini S. 2019. Postharvest Responses of Hydroponically Grown Lettuce Varieties to Nitrogen Application Rate. Journal of Integrative Agriculture.

Mutia , A. K., Purwanto, Y. A., dan Nugroho, L., P.E. 2015.Penyimpanan Bawang Merah (Allium ascalonicum L.) pada Suhu Rendah dan Tingkat Kadar Air Awal Berbeda. Jurnal Pascapanen.

Pantastico, B. E. R. 1986. Fisiologi Pascapanen. Yogyakarta. Gadjah Mada University Press.

Sagas, Emi Y., Frans Wenur \& Lady C. Ch. E. Lengkey. 2015. Kajian Penggunaan Kotak Pendingin menggunakan Hancuran Es untuk Distribusi Pak Choi (Brassica rapa). Universitas Sam Ratulangi. Manado. Van Den Berg, L. \& C. P. Lenz. 1973. High Humidity Storage of Carrots, Parsnips, Rutabagas and Cabbage. $J$. Am. Soc. Hort. Sci. 98: 129-1 